CZU:821.135.1-292.09

https://doi.org/10.52505/filomod.2021.15.06

\title{
O PROBLEMĂ DE CIRCULAȚIE FOLCLORICĂ DINTR-O PERSPECTIVĂ COMPARATĂ
}

\author{
TATIANa BUTNARU, doctor în filologie \\ Institutul de Filologie Română „B. P.-Hasdeu” al MEC
}

Rezumat. In articolul de faţă este propusă spre analiză balada Voichiţa, cu versiunile sale româneşti, greceşti sau sârbești, de o largă circulaţie în arealul dacoromân. Balada este cunoscută la mai multe popoare şi, după opinia specialiştilor, „subiectul artistic exploatează o concepție tipică sud-est-europeană”. Este o baladă fantastică, de circulație universală, cu diferite întâmplări neprevăzute şi colizii de natură etică , care se menține în limita dintre ficţiune şi realitate. In baladă este zugrăvită o realitate, de o largă semnificație epică, care se sprigină pe ritualurile de la nunţi şi inmormântări, relevă anumite fenomene, situații de viaţă arhaicăa, legate de practici şi interdicţii specifice în modul de existenţă al familiei patriarhale. Blestemul matern şi călătoria fratelui mort aprofundează nucleul epic al narațiunii, ce va menţine subiectul, in zona fabulosului mitic. Privită dintr-o altă perspectivă, balada vizează acţiunile omeneşt $i$, aftate sub semnul predestinării malefice, în mrejele misterelor demonice.

Cuvinte-cheie: epica populară daco-română, straturi de vechime culturală, tipul elino-albano-român, blestem funcţional, complex mitico-ritualic, predestinare malefică, elemente lirico-narative.

Abstract. In this article, the ballad Voichitg with its Romanian, Greek or Serbian versions is proposed for analysis, with a wide circulation in the Daco-Romanian area. Southeast Europe". It is a fantastic ballad of universal circulation, with various unforeseen events and ethical collisions, which is kept on the border between fiction and reality. It depicts a world of great epic significance, which is based on the rituals of weddings and funerals, reveals some phenomena, archaic life situations, related to specific practices and prohibitions in the existence of a patriarchal family. The maternal curse and the journey of the dead brother deepen the epic nucleus of the narrative, but will at the same time keep the subject in the area of the fabulous myth. which is intertwined with a series of beliefs about undead and other evil spirits.

Keywords: daco-romanian folk epic, layers of cultural antiquity, hellenicalbanian-romanian type, functional curse, mythical-ritual complex, evil predestination, lyrical-narrative elements.

Voichiţa este una din cele mai reprezentative lucrări în eposul nuvelistic, „,această baladă este o nouă formă românească a legendei despre Călătoria mortului, comună la toate popoarele Peninsulei Balcanice" (Caracostea, 1969, p. 321) şi se bucură de o largă circulaţie ,în mai toată Europa” (Papahagi, 
p. 162). Subiectul în discuţie este omniprezent la mai multe popoare: greci, bulgari, albanezi, sârbi, aromâni, are o arie extinsă de răspândire în România, precum şi în unele localităţi din diasporă. Problema originii, dar şi vechimea acestei balade a fost abordată de nenumărate ori în investigaţiile unor folclorişti de prestigiu, ea „poare fi explicată în funcţie de consideraţiuni de vechime culturală şi civilizaţie a unui popor" şi, după cum suntem informaţi în unele studii”, grecii ar fi primit această legendă de la bulgari sau de la sârbi, în al căror folclor ea circulă, sau prin intermediul acestora, din nordul Dunării, de la dacoromani" (Papahagi, 1975, p. 162). Aserţiunea potrivit căreia, acest subiect de circulaţie universală ,... s-a născut într-un singur punct geografic, de unde cu timpul, a radiat în direcţii multiple şi că existenţa ei în epica populară dacoromână are origine sud-dunăreană" (Papahagi, 1970, p. 162), este confirmată printr-o cercetare teoretică în studiile mai multor specialişti în domeniu, s-a bucurat de cele mai variate interpretări, analize, aprecieri, comentarii, unde au fost dezvăluite calităţile tipice ale baladei, particularităţile ei de naraţie şi transfigurare artistică, trăsăturile estetice bine individualizate. Asemenea tip de balade, după cum ne atenţionează şi cercetătorul M. Pop”, au o structură proprie, caracter nuvelistic, uneori senzaţional, teme şi subiecte de o largă răspândire europeană şi numeroase elemente lirice" (Pop, 9, p. 6). În ceea ce priveşte vechimea baladei, problema respectivă a fost elucidată cu lux de amănunte de mai mulţi exegeţi, iar rădăcinile ei par a fi întrezărite încă în cultura bizantină, bunăoară, Baud-Bovy o consideră ,une tres ancienne chanson byzantine, originaire de l'Asie mineure" (Papahagi, 1970 p. 162). Naraţiunea epică dezvoltă acest subiect de circulaţie universală şi se referă, în special, la relaţiile de familie, dezvăluind într-o modalitate fantastică ,aspecte de viaţă arhaică legate de modul de existenţă a familiei şi funcţiile membrilor acestuia" (Cârstean, 1984, p. 77). Prin însăşi esenţa sa, Voichiţa este o baladă fantastică, care dezvăluie şi aprofundează relaţiile din familia patriarhală, diferite situaţii de ordin moral şi social, fiind axată pe motivul călătoriei fratelui strigoi. Este o baladă de circulaţie universală, cu diferite întâmplări neprevăzute şi colizii de natură etică, care se menţine în limita dintre ficţiune şi realitate. Este zugrăvită o lume, de o largă semnificaţie epică, care se sprijină pe datinile, credinţele, ritualurile de la nunţi şi înmormântări, relevă nişte fenomene, situaţii de viaţă arhaică, legate de practici şi interdicţii specifice în modul de existenţă al unei familii patriarhale, calificată drept „o structură de familie mare”, instituită „odată cu instalarea slavilor în zonă” (Fochi, 1975, p. 218), o problemă care se manifestă ,în mod egal” în folclorul mai multor ţări europene. Odată ce „toate popoarele din zonă şi-au pus la un moment dat aceleaşi probleme de viaţă şi de concepţie”, fenomenul în cauză a determinat ,răspândirea aceloraşi subiecte de baladă la toate aceste popoare", (Fochi, 1975, p. 118), pentru că normele de conviețuire ,nu reglementau numai relaţiile dintre om şi societate, ci şi relaţiile familiale, norme atât caracteristice încât au trebuit să fie recunoscute şi respectate de toţi ca semn al unei culturi specifice" (Fochi, 1975, p. 219). În această ordine de idei, desfăşurarea epică variază între real şi fantastic, urmat 
de o serie de conflicte şi colizii interioare, marcat de un substrat arhaic, cu rădăcini adânci în spiritualitatea diferitor popoare. Sfera vieţii de familie redată în manifestările ei tipice, caracteristice vieţii de epocă, constituie şi nucleul tematic al baladei Voichiţa. Elementele lirico-narative derivă dintr-o profundă dramă existențială, cauzata de o serie de fapte şi întâmplări, contradictorii prin însăşi esenţa lor, unde lipsa ideii despre moralitate se manifesta din plin, ceea ce va duce după sine la un dezechilibru în viaţa de familie, problemă concretizată printr-o serie de interdicţii şi sentinţe implacabile. Elementele etnografice, care au determinat apariţia baladei sunt încadrate în contextul unor epizoade şi aspecte tipice de transfigurare a realităţii, în corespundere cu diferite credinţe, superstiţii, întâmplări miraculoase. În contextul mai multor subiecte baladeşti, persistă diverse stări sufleteşti, frământări lăuntrice, situaţii de viaţă, personaje tipice, care ,atribuie naraţiunii o logică epică şi o evoluţie firească”, (Vrabie 1966, p. 137), în conformitate cu anumite modele din experienţă universală. Din analiza versiunilor şi a tipurilor de variante înregistrate pe teren, balada despre călătoria fratelui strigoi este orientată, după opinia specialiştilor", către două mari cicluri aflate în circulaţie şi , anume, tipul „elino-albano-român, la care se mai adaugă cea mai mare parte din versiunea bulgară nord-estică şi variantele aromâne", pe de o parte, iar pe de altă parte, se are în vedere balada „sârbo-vest bulgară” (Vrabie, 1966, p. 140). Din relatările expuse rezultă ideea, că ,...cele două cicluri ale motivului epic în discuţie: elino-albano-român şi sârbo-vest-bulgar" se referă la dezvăluirea unor secvenţe tipice de viaţă patriarhală din sfera vieţii de familie, în deosebi, este dezvăluită situaţia unei mame însingurate, nevoită să se despartă de unica fiică, precum şi blestemul acesteia asupra fiului trecut în lumea celor drepţi, de aceea, în contextul semnalat, ce mai face referinţă la semnificaţia datinilor şi ritualurilor de înmormântare. Tipul al doilea îşi va trage originea dintr-o serie de tradiţii, ce ţin de cântecele de nuntă, având tangenţă cu drama existențială a fiicei înstrăinate şi măritate în depărtări. Aceste motive se suprapun reciproc, creând nişte situaţii neverosimile, când în prim plan se impune o lume a fantomelor, marcate de umbre şi chipuri fantastice, autorul anonim încearcă să profileze un univers existenţial specific, unde aproape toate evenimentele se desfăşoară într-o anumită consecutivitate, în conformitate cu anumite principii de transfigurare estetică. Aşa-zisa „profilare ciclică” a materialului factologic este determinată de mai multe epizoade, care într-un fel oarecare vor motiva culminaţia emoţională a blestemului. În tradiţia folclorică a românilor, dar în acelaşi timp, la sârbi şi la bulgari, drama existenţială a familiei se produce din cauza unei calamităţi sociale, ce a survenit pe neaşteptate, este vorba de o situaţie imprevizibilă cauzată de ciumă, din care cauză feciorii, în acelaşi timp, şi Constantin, mezinul familiei, nu şi-a respectat jurământul faţă de mamă şi ea va rămâne, 
„ca şi cucul singurea”. Naraţiunea epică, precum şi situaţiile improvizate, redau o situaţie tragică în esenţă.

Ciuma-n sat s-o-ndemnat,

Toţi feciorii i-o luat.( AF AŞM, 1984, p. 165-166),

Iar

Mă-sa singură rămânea

Şi tot se bocea... (Balada populară, 1976, p. 123-128).

Într-o versiune sârbă, „mama rămasă singura supraviețuitoare, în urma acestei calamităţi teribile, se plimbă pe străzile oraşului Mostar printre cadavre" (Vrabie, 1966, p. 113). Situaţia descrisă şi-a găsit expresie şi în unele subiecte baladeşti din Basarabia, unde descrierea tragediei capătă o notă particulară şi o nuanţă locală. În această ordine de idei, atestăm nişte similitudini cu baladele Ciuma, Holera, unde naraţiunea epică este încadrată într-o serie de epizoade şi forme poetice, expuse într-o manieră specifică. Moartea, ciuma, holera sunt nişte întruchipări poetice demistificate şi poartă o semnificaţie arhetipală. De astă dată, personajul epic nu mai are o atitudine eroică faţă de moarte, din contra, ea este privită drept un fenomen fatal, exprimând certitudinea de resemnare totală şi eşec sufletesc exteriorizat în plan interior:

Foaie verdi arnăut,

Scobori, Doamne, pi pământ

Şi vezi ciuma şi-a făcut.

De la Nistru pân la Prut,

Au făcut negru pomânt.

Printre vii, printre livezi,

Tot mormânturi di băieţi.

Printre viile şele mari,

Mormânturi di fete mari.

Printre viile şele mişi,

Tot mormânturi di voiniși (AF AȘM, 1953, f. 101).

La lectura baladei Voichiţa, la fel ca şi în alte scrieri epice, un loc aparte îi revine elementului funcţional, blestemul, ,în toate variantele este accentuat blestemul matern" (Fochi, 1975, p. 33), ne atenţionează A. Fochi, iar acesta aprofundează întreaga dezvoltare a subiectului.

De subliniat, blestemul mamei şi călătoria fratelui mort, nu numai că determină nucleul epic al naraţiunii, dar va menţine subiectul într-un context fabulos de sorginte mitică. Expunerea motivului are loc ,sub forma unei analize sincronice”, în dependenţă de ,,anumite unităţi episodice” (Vrabie, 1966, p. 136), la nivelul unor posibilităţi specifice de transfigurare a evenimentelor de epocă. De aceea, desfăşurarea epică se derulează în dependenţă de aprofundarea materialului factologic aflat în circulaţie, de individualizarea personajelor şi relevarea unor situaţii neverosimile. Analizând diferite versiuni ale subiectului respectiv la popoarele europene, A. Fochi subliniază ideea că „subiectul exploatează artistic o concepţie tipică sud-est-europeană” (Fochi, p. 219) şi anume, „credinţa în eficacitatea blestemului”, ceea ce în accepţia 
cercetătorului nu este altceva decât „magia cuvântului” (Fochi, 1975, p. 219), având menirea să asigure integritatea familiei. Elementele lirico-narative derivă dintr-o profundă dramă existenţială cauzată de încălcarea interdicţiei mitice, aflată sub puterea totalizatoare a blestemului matern. Este vorba de un blestem funcţional, contaminat ,cu specifice accente ale unui anumit sentiment al destinului" (Hâncu, 1993, p. 125), dar şi printr-o analogie lirică cu drama fetei măritate în depărtări. De aceea, în marea lor majoritate, folcloriştii se referă „la recepţiunea baladelor înstrăinării”, făcând referinţă, în primul rând, la balada „fratelui strigoi”, aceasta fiind ,,încadrată în ansamblul liric corespunzător şi în toate motivele epice înrudite" (Caracostea, 1969, p. 513). Blestemul din cântecele înstrăinării sau „les chanson de mal mariee” (Caracostea, 1969, p. 481), cum le mai numeşte D. Caracostea, îi oferă eroinei posibilitatea din mai multe texte şi scrieri baladești, să-şi exprime protestul ori sentinţa implacabilă, de astă dată adresată părinţilor, pentru drama ei personală,

Părinciorii blestemând,

N-or avea loc în pământ,

Că m-au dat după urât.

Nici tămâie pe mormânt,

Nici abur călăii,

Care mi-o făcut-o mii,

Să fiu casa cucului

Şi odihna lupului ( AF AŞM, 1976 , p. 58).

Aflată într-o dezolare totală, în deplină singurătate, în balada Voichiţa, mama îşi blestemă fiul plecat pe celălalt tărâm, ceea ce determină intriga naraţiunii. În una din variantele înregstrate în Basarabia, autorul anonim ne relatează că atunci când feciorul a murit ,şi gândul nu şi-a-mplinit”, iar mama rămâne singură, pradă deznădejdii :

„Mergea la ţântirim şi plângea:

Dragii mei feciori,

Fie-vă somnul uşor

Dar la Constantin când mergea

Din gură blestema

Şi amarnic cuvânta:

Constantine, Constantine,

Să fii blestemat de mine,

Blestemat să fii de mă-ta,

Tu ai dat pe soră-ta,

Tu ai dat-o, blestemate,

Pământul nu te primească,

Pământul să te izbească” (AF AŞM, 1985)

Blestemul devine, în felul acesta, un strigăt de durere, dar şi de revoltă, indică undeva în subtext chiar şi o nuanţă de răzbunare, întrucât fiul nu şi-a îndeplinit jurământul faţă de mama. Cel aflat sub puterea predestinării malefice a blestemului nu-şi poate găsi linişte nici în mormânt, de aceea, el 
se află într-un impas existenţial specific de remediere, inaccesibil cunoaşterii terestre. Autorul anonim prezintă faptele şi întâmplările, ce vor urma în continuare, drept consecinţă a remedierii şi diferenţierii celor două lumi, de aici și cea de dincolo:

Vai blestemul s-a legat,

Într-un amurg de seară

Iese Constantin afară (AF AŞM, 1985, f. 123).

În analogie cu o versiune grecească, tradusă şi prelucrată de T. Papahagi, blestemul matern capătă o intensitate zguduitoare şi este plasat, în conformitate opinia lui A. Fochi, ,în categoria tipului 1” ( Fochi, 1975, p. 92), acesta fiind evidenţiat în corespundere cu mai multe modele de circulaţie baladescă şi care se prezintă în felul următor:

De multe anateme, de greul ei blestem

S-a zguduit pământul şi Constantin ieşit-a (Papahagi, 1970, p. 161).

De subliniat, blestemul persistă aproape în toate variantele înregistrate pe teren la diferite popoare, dar capătă o coloratură deosebită, cu o vădită nuanţă etnografică, în special, în versiunile greceşti, unde se profilează prin nişte acorduri de un tragism tulburător, „,pe calea transfigurării poetice mai geometrice" (Vrabie, 1966, p. 172), consecinţa unui dezechilibru sufletesc, la care este predispusă eroina. În cele din urmă, blestemul capătă o tonalitate macabră, de intensitate dantescă: ,te blestem, Constantine, de mii de ori te blestem, că mi-ai înstreinat-o pe fata-mi Aretia” (1970, p. 160) sau „ferul şi oțelul, el să putrezească - / trupu - ţi să - nverziască, / să nu putrezească" (Papahagi, 1970, p. 170). Talentul autorului anonim constă în exteriorizarea unor situaţii sumbre, de un tragism zguduitor, care atinge o dimensiune absolută, se manifestă prin tendinţa de a sensibiliza sufletul omenesc, prin capacitatea de răvăşire dramatică spontană. Apoi, după cum sesizăm în continuare, mama:

„La toate mormintele plângea

Numai la al lui Constantin blestema

şi-şi smulgea părul, că a rămas singură ca trestia, ca o biserică părăsită, ca un sat prădat" (Vrabie, 1966, p. 172). Versiunea greacă a baladei, La chevauchee funebre, evidenţiază în mod tulburător această dramă de familie, fapt datorită căreia exegeţii ajung la o concluzie generalizatoare, unde recunosc superioritatea ei estetică faţă de circulaţia altor texte: „... raportat la oricare variantă daco-romană, prototipul grec ni se prezintă ca un edificiu cu temelii puternice, adâncite în teren prielnic, cu osatură bine şi solid închegată, cu orizont precis şi cu echilibru clasic în întreaga lui înfăţişare artistică, precum şi în emoţia ce o prilejuiește" (Papahagi, 1970, p. 164).

Îngrijirea morţilor după obiceiul locului constituie un moment impresionant în contextul baladei Voichiţa. La trecerea fiilor în nefiinţă, mama:

Pe opt îi grijea,

Şi-i spovedea,

Baba că-ngrijea,

Apă le căra 
Şi-i tămâia,

Turte la zile mari da (Vrabie, 1966, p. 122),

pe când Constantin este neglijat în mod intenţionat:

Pe Din Constantin,

Tot îl oropsea

Şi nu mi-1 grijea,

Nici nu-1 tămâia,

Nici turte nu-i da,

Nici apă nu-I căra,

Ca un buştean pârlit era (Vrabie, 1966, p. 122).

Factura realistă a imaginii folclorice dezvăluie o situaţie dramatică în evoluţia motivului şi se manifestă în dependenţă de contaminările exterioare, iar deznodământul poartă o amprentă interioară specifică. Pentru comparaţie, cităm şi un fragment dintr-o versiune ucraineană, unde vedem această diferenţiere macabră chiar şi în lumea celor morţi:

Fiul a murit seara

Iar nora dimineața.

Pe fiu îl îmbracă frumos pe catafalc...

Şi fiului îi aprinde lumânarea,

Iar pe noră a rămas pusă o cociorvă (Vrabie, 1966, p. 480).

Un caz similar atestăm într-o versiune greacă, unde măicuţa îndurerară răsădeşte flori pe cele opt morminte, dar pe cel al lui Constantin nu seamănă nimic, pe mormântul lui se află „numai poteci şi drumuri”, o sugestie metaforică, că ,cel blestemat s-a transformat în strigoi, care după credinţele poporului, joacă în jurul groapei” (Vrabie, 1966, p. 172).

Călătoria fratelui mort spre sora sa măritată în depărtări şi readucerea ei la casa părintească, unde se află măicuţa bătrână, zdrobită de durere şi singurătate, constituie o secvenţă tulburătoare în balada respectivă, dar în acelaşi timp, ea se impune drept o „probă dramatică” (Cârstean, 1984, p. 81), pentru ca mezinul să se izbăvească de puterea malefică a blestemul matern. Pe de altă parte, are loc legătura cu o realitate etnologică de altă natură, este vorba „de un fapt petrecut cândva şi undeva - măritarea în streinătate a unicei surori a celor nouă fraţi” (Papahagi, 1975, p. 163). Cu această ocazie, balada prezintă fapte tipice de viaţă, dezvăluie moravuri, situaţii reale, întâmplări consecutive, toate acestea, fiind încadrate în sfera unui deznodământ epic fabulos. De subliniat, drama mamei rămasă în deplină singurătate îşi găsește continuitate prin soarta şi situaţia nefavorabilă a sorei măritată în depărtări, ,peste plai”, care zadarnic îşi aşteaptă rudele, ca să-i facă vizita tradiţională după nuntă. Într-o variantă sârbă se spune: „... A trecut o săptămână, două, trei şi n-ă venit nimeni, a trecut o jumătate de an, un an şi tot n-au venit. Cumnatele, cumnaţii, soacra, socrul încep s-o privească curios, jignind-o prin cuvinte tari: câine să fi fost şi fraţii tăi ar fi venit la tine" (Vrabie, 1966, p. 215). Trecut oarecum cu vederea în versiunile româneşti, epizodul acesta este accentuat mai ales într-o serie de cântece sârbeşti sau greceşti, „incidental” 
se întâlneşte ,atât la bulgari, cât şi la aromâni”, dar în toate cazurile există o analogie directă cu ciclul baladesc Fiica înstrăinată şi, după cum se subliniază în continuare, ,se observă câtă importanță se bucurau în viaţa sârbilor vizitele, pe care le făceau rudele, fraţii mai întâi de toate, surorii în curând măritată" (Vrabie, 1966, p. 215). O reminiscență a acestor ritualuri după căsătoria fiicei în depărtări, la ,părinţi necunoscuţi”, atestăm în mai multe variante din ciclul baladesc Fiica rău măritată sau Fiica înstrăinată, cu o răspândire evidentă în arealul basarabean. În unul din textele înregistrate pe teren se spune:

$\mathrm{N}-\mathrm{a}$ trecut un an de zile,

Vine mama pe la mine,

De pe uşă a lăcrămat

Şi pe mine m-a întrebat:

Cum ţi-i fiică la bărbat! (AF AM, 1959, f.211-212).

Expresie a fanteziei poporului, cu un înţeles simbolic adânc, vedem într-o versiune sârbească, unde depistăm o scenă cutremurătoare. Atunci când situaţia sorei în familia soţului devine apăsătoare", dispreţuită de rude şi batjocorită de cumnate, cu sufletul plin de durere, ea face nouă păpuşi, cărora le pune numele fraţilor săi, iar după aceasta pregăteşte o masă ritualică, ceea ce în accepţia tradiţiei folclorice a locului semnifică faptul că fraţii sunt morţi, iar ea le face „obişnuitul parastas” (Vrabie, 1966, p. 115) de înmormântare. Lasă impresia, în această ordine de idei, că sora trece printr-o experienţă similară cu cea a mamei, aflându-se şi ea într-o deplină singurătate şi decepţie sufletească. Din aceste considerente, folcloriștii ajung în cele din urmă la altă concluzie şi anume, ,autorul anonim aşază de la început în centrul acţiunii drama surorii”, întrucât ea este „eroina principală şi nu mama, cum apare în versiunea grecească sau românească" (Vrabie, 1966, p. 122). Este o problemă cu mai multe aspecte discutabile, în acelaşi timp, şi care pot fi interpretate în dependenţă de materialul factologic aflat în circulaţie.

Concomitent, în balada Voichiţa, mai sunt dezvăluite diferite credinţe ale popoarelor despre spiritele malefice ale morţilor, care au o influenţă nefastă asupra oamenilor şi atentează la liniştea celor vii. Reprezentările malefice, prescrise din complexul mitico-ritualic originar, se manifestă printr-un joc al imaginaţiei şi fanteziei populare, de unde transpare o lume a fantomelor, populată de umbre şi chipuri fantastice. Metamorfoza mortului în strigoi, precum şi călătoria acestuia împreună cu sora spre casa părintească, se manifestă prin nişte situaţii bizare, neobişnuite, fantastice, parcă venite de pe alte tărâmuri, lăsând cititorul să înţeleagă, că cele întâmplate „s-a petrecut într-o lume a duhurilor nefaste" (Vrabie, 1966, p. 135), unde parcă este improvizată „o horă a strigoilor” (Vrabie, 1966, p. 129), aflată sub semnul predestinării malefice. Starea de nelinişte şi angoasă este cauzată atât de încălcarea interdicţiei mitice, cât şi de tulburarea somnului celor adormiţi. Blestemul mamei, cu efectele sale imprevizibile, este marcat de o „credinţă-superstiţie”, „...impresionând şi fecundând acea sanctam 
simplicitatem a timpurilor trecute" (Papahagi, 1970.p.163), el capătă o semnificaţie malefică asupra întregului univers existenţial al familiei şi anihilează, în genere, ideea de viaţă. Fiul aflat sub puterea malefică a blestemului nu-şi găseşte linişte nici în mormânt, de aceea el ,planează” în spaţii ontologice diferite, având menirea de remediere şi diferenţiere a celor două lumi, de aici şi cea de dincolo, inaccesibilă cunoaşterii umane. Nu numai în balada Voichiţa, dar şi în mai multe scrieri folclorice motivarea blestemului se manifestă prin nişte nuanţe specifice de ,patriarhalism superstiţios" (Papahagi, 1970, p. 163) şi are nişte efecte imprevizibile, cum încearcă să ne convingă în studiile lor mai mulţi exegeţi. Or,

Şi blăstămul de părinte

E ca focul de fierbinte,

Şi blăstămul de măicuţă,

Cum te-ar arde în păruţă (Bud, 1908, p. 24-25).

sau

\section{Blăstemlu di părinţî}

Ti - avână ş’ tu murmânţî (Calendarul aromânesc, 1912, p. 122).

Deznodământul tragic din majoritatea versiunilor baladeşti confirmă ideea, că blestemul părintesc este cea mai dureroasă povară, iar pe de altă parte, unii cercetători încearcă să demonstreze ,absurditatea acestui blestem: mama cere feciorului mort să aducă acasă pe fata ei, care după sfatul lui se căsătorise în depărtare, dar aducerea acasă fratele n-o putea face decât ca strigoi”, (Caracostea, 1969, p. 329). Din aceste considerente, exegetul lasă să se înţeleagă, din situaţ̧ia descrisă, atunci când fratele mort devine strigoi ,şi pentru fată, şi pentru mamă este o osândă mai grea decât depărtarea" $(1969$, p. 329). Iată de ce, D. Caracostea întrevede în continuare în Voichița „,o povestecoşmar" (1969, p. 325), unde elementele de incertitudine sufletească, tragice în esenţă, sunt marcate de o coloratură sinistră, se referă la nişte momente inexplicabile a cunoaşterii umane. Privită dintr-o altă perspectivă, balada vizează acţiunile omeneşti aflate sub semnul predestinării malefice, în mrejele misterelor şi acţiunilor demonice întunecate, fenomen ce se împleteşte cu o serie de credinţe ale românilor despre strigoi şi alte spirite nefaste, ce bântuie cimitirele. $\mathrm{Cu}$ această ocazie, A. Fochi ajunge la o concluzie absolut diferită de cele anterioare, el spune: ,...Textul exploatează şi o altă componentă specifică a culturii populare albaneze, şi anume jurământul besa, a cărui încălcare are consecinţe şi asupra vieţii de apoi. Cu atmosfera sa funebră, acest subiect ne transmite idei şi credinţe dintre cele mai vechi şi comunică ceva din teroarea, pe care dintotdeauna au exercitat-o morţii asupra lumii celor vii”" (Fochi, 1975, p. 33). În mod nemijlocit, aserţiunea înclină spre evidenţierea şi a unei sentinţe moralizatoare, alături de cea funcţională. Prezenţa elementului macabru îşi găseşte explicaţie prin aceea, că personajele, în primul rând mama, încalcă interdicţia prescrisă, tulburând firea obişnuită a cursului existenţial al vieţii şi, în primul rând, somnul celor trecuţi în lumea de dincolo de nefiinţă, de aceea 
va fi şi ea pedepsită, în corespundere cu principiile eticii populare . Astfel, în finalul baladei, mama

\author{
„Pă Voic-o vedea, \\ În braţă mi-o lua \\ Şi mi-o săruta, \\ Doamne, că mi-ş' cădea, \\ Baba-m' leşâna \\ Ş-în o' i n-o mai vedea" (Amzulescu, 1983, p. 75).
}

Şi de astă dată naraţiunea epică este determinată de un moment funcţional, care se manifestă printr-o situaţie de încordare şi maximă tensiune lăuntrică. În majoritatea variantelor, atât greceşti sau sârbeşti, cât şi unele din cele româneşti, linia de subiect capătă un vădit caracter legendar, iar mama şi fiica, după ce s-au întâlnit, vor muri îmbrăţişate. În alte versiuni, în cele din urmă, eroinele vor fi ,transformate în stei de piatră” (Vrabie, 1966, p. 136), autorul popular, împrumutând, astfel, o nuanţă din ritualul statorniciei prin pietrificare, caracteristic în această privinţă pentru legendele Dochiei. O evoluţie specifică, în sens legendar, persistă într-o variantă greacă, unde fiica contemplează cu durere ,pustietatea, în care a găsit castelul părintesc, plângând, ea se îndepărtează de casă şi ajungând într-o pădure, se aşază lângă un brad, iar Dumnezeu îi dă aripi, transformând-o în cucuvaie", ca să-şi deplângă „soarta jalnică, despre care povesteşte poporul” (Vrabie, 1966, p. 136). Metamorfoza fetei în pasăre nu este întâmplătoare, deoarece cucuvaia ,plânge cu o voce amărâtă ce parcă iese din mormânt” (Papahagi, 1979, p. 190). În ipostaza de ,pasăre mitică” (Vulcănescu, 1987, p. 269) şi a predestinării, dar şi de topos folcloric, cucuvaia mai este şi o ,pasăre de noapte” şi, în acelaşi timp, „o pasăre a tristeţii, a jalei şi a morţii”, cu ochii strălucind în întuneric şi cu strigătul lugubru, ,ea capătă asociaţia „,duhurilor nopţii”, ţine de atmosfera macabră a ,tărâmului morţii, mesajerilor din alte lumi”, „domină tenebrele necunoaşterii” (Evseev, 1997, p. 102), este „o pasăre funerară" (Vulcănescu, 1987, p. 269). Pe lângă sugestia metaforică a morții, în contextul semnalat, pasărea mai vine să aprofundeze o stare de apăsare sufletească chinuitoare într-un univers existenţial specific, marcat de dezolare şi incertitudine, este ,zvârcolirea sufletească a omului”, ,strădania zădarnică” (Rusu, 1967, p. 32) a celui aflat sub ameninţarea „,necazurilor cosmogonice" (Vulcănescu, 1987, p. 311).

Din cele enunţate mai sus, autorul anonim lasă să se înţeleagă, ca drama tuturor personajelor din balada Voichiţa este consecinţa unor acţiuni imprevizibile, aproape în toate variantele, şi-a găsit expresie un întreg sistem de reglementări şi interdicţii, în afara cărora existenţa omenească este imposibilă, în acelaşi timp, mai este vorba şi de destinul omului, fiind influenţat de cele mai multe ori de „formula imposibilului” (Roşianu, 1981, p. 99 ), din care cauză se va ajunge la acest sfârşit trist, de un vădit caracter legendar. „Este norocul sau nenorocul omului" (Fochi, 1971, p. 307), interceptat printr-o 
seninătate lăuntrică, caracteristică spiritului mioritic, în dramatica aprofundare a rosturilor existenţiale şi contemplarea unui sfârşit fatal.

Unică în felul ei, balada Voichiţa nu se aseamănă cu nici o lucrare din eposul nostru nuvelistic, în cadrul ei şi-a găsit expresie concepţia de viaţă a diferitor popoare, capacitatea de a dezvălui realităţile dramatice ale timpului, condensate într-o structură de elegie populară, creând o operă folclorică de substanţă, de o vădită semnificaţie artistică.

\section{Referințe bibliografice:}

1. AF AŞM, 1953, ms. 59, f. 101, Hânceşti, inf. N. Stoian, culeg. M. Savin. Minciună

2. AF AŞM, 1959, ms. 115, f. 211-212, Criva-Lipcani, inf. M. Minciună, culeg. T.

3. AF AŞM, 1976, ms. 19, f.57-59, Orlovca (Cartal) - Reni - Odessa, inf. A. Bogdan, culeg. E. Junghietu.

4. AF AŞM, 1984, ms.350, f. 165 -166, Slatina - Teceu - Ucraina, inf. F. Hervat, culeg A. Hâncu, Gr. Botezatu.

5. AF AŞM, 1985, ms. 373, f. 123, Boian-Novoseliţa-Cernăuţi, Ucraina, inf. A. Gerasim, culeg. Gr. Botezatu.

6. AMZULESCU, Alexandru. Balada familială. Tipologie şi corpus de texte poetice. Bucureşti, ed. Academiei, 1983.

7. Balada populară. Alcătuirea, articolul introductiv şi comentariile de A. Hâncu. Chişinău, ed. Știința, 1976.

8. BUD, Tit. Poezii populare din Maramureş. Bucureşti, 1908.

9. Calendarul aromânesc pe anul 1912.

10. CARACOSTEA, Dumitru. Poezia tradiţională română. Bucureşti, ed. pentru Literatură, V.2, 1969.

11. FOCHI, Adrian. Coordonate sud-est europene ale baladei populare româneşti, Bucureşti, ed. Academiei, 1975.

12. EVSEEV, Ivan. Dicţionar de magie, demonologie şi mitologie românească. Timişoara, ed. Amarcand, 1997.

13. HÂNCU, Andrei. Geneza Mioriţei - mit şi realitate. În: Revistă de lingvistică şi ştiinţă literară, 1993, nr. 5.

14. PAPAHAGI, Tache. Paralele folclorice. Bucureşti, ed. Minerva, 1970.

15. PAPAHAGI, Tache. Mic dicţionar folcloric. Spicuiri folclorice şi etnografice comparate. Bucureşti, ed. Minerva, 1979.

16. POP, Mihai. Caracterul istoric al epicii populare. În: Revistă de etnografie şi folclor, an 9 , nr. 1.

17. RUSU, Liviu. Viziunea lumii în poezia noastră populară. Bucureşti, Ed. pentru Literatură, 1967.

18. ROŞIANU, Nicolae. Eseuri despre folclor. Bucureşti, ed. Univers, 1981.

19. VRABIE, Gheorghe. Balada populară română. Bucureşti, ed. Academiei, 1966.

20. VULCĂNESCU, Romulus. Mitologie română. Bucureşti, ed. Academiei, 1987.

Notă: Articolul a fost realizat în cadrul proiectului de cercetare 20.80009.1606.03 Contexte socioculturale autohtone şi interconexiuni europene în creaţia populară şi literatura cultă din Basarabia (sec. XIX până în prezent), Institutul de Filologie Română „B. P.-Hasdeu” al MEC. 